Research upotate

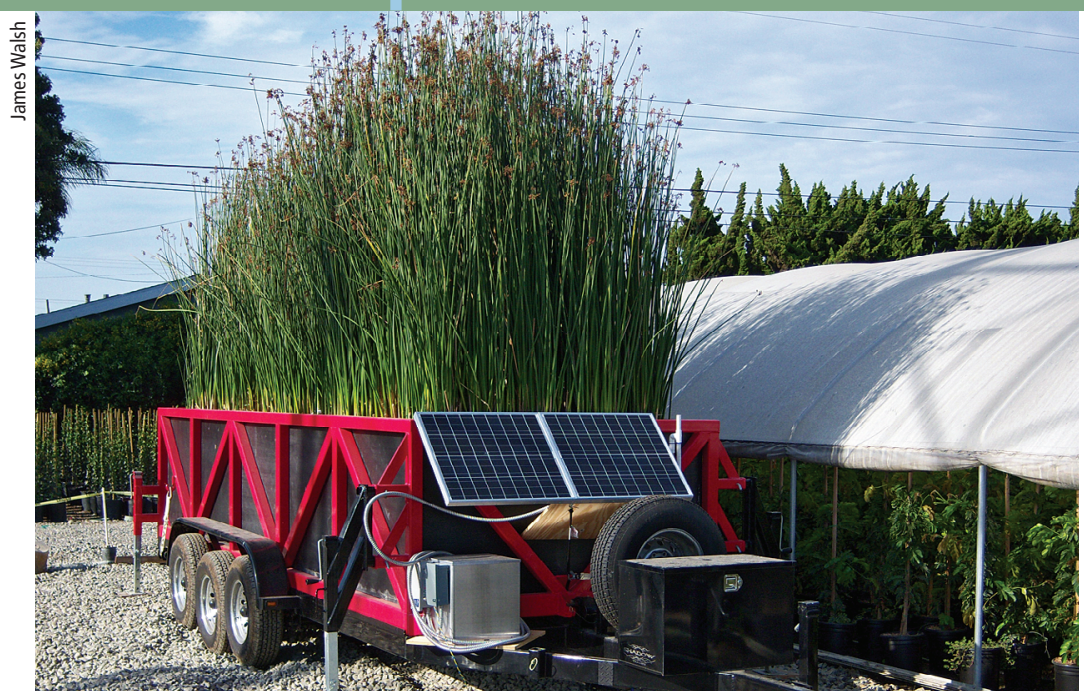

\section{Regulators and researchers seek innovative water-quality solutions}

The quality of California's surface waters is regulated by two agencies: the U.S. Environmental Protection Agency (U.S. EPA), under the 1972 Clean Water Act, and the State Water Resources Control Board, which was established in 1967.

Under the Clean Water Act, the federal government took responsibility to regulate point-source pollution, while calling for state and local governments to regulate nonpoint-source pollution through regional plans. As a result, federal and state agencies have taken different approaches and set somewhat different water-quality standards, whether for pathogens, sediment, nutrients, pesticides or temperature.

The federal approach is based on how much of each pollutant is allowed in a given body of water (the total maximum daily load, or TMDL). In contrast, the state approach is based on controlling pollutants throughout a given watershed. California is divided into nine major watersheds, each with its own Regional Water Quality Control Board that sets its own standards. Not surprisingly, differences can arise among water-quality regulators. For example, both federal and state pathogen regulations use indicator bacteria such as Escherichia coli, however federal rules are based on $E$. coli levels, while most regional boards look at all coliforms (see page 159).

- Editors

California's perennial water woes are now critical. Contributing factors include record drought conditions in parts of the state; increasing demands from a fast-growing population; deterioration of the San Francisco Bay-Delta infrastructure; an August 2007 federal court order to protect the endangered delta smelt by dramatically reducing water deliveries to agriculture and residences; and global climate change.

"We cannot wait until we have a Katrinalike disaster to attack this problem," Governor Schwarzenegger said during a water summit with Senator Dianne Feinstein in August. In midSeptember, the Governor proposed $\$ 9$ billion in

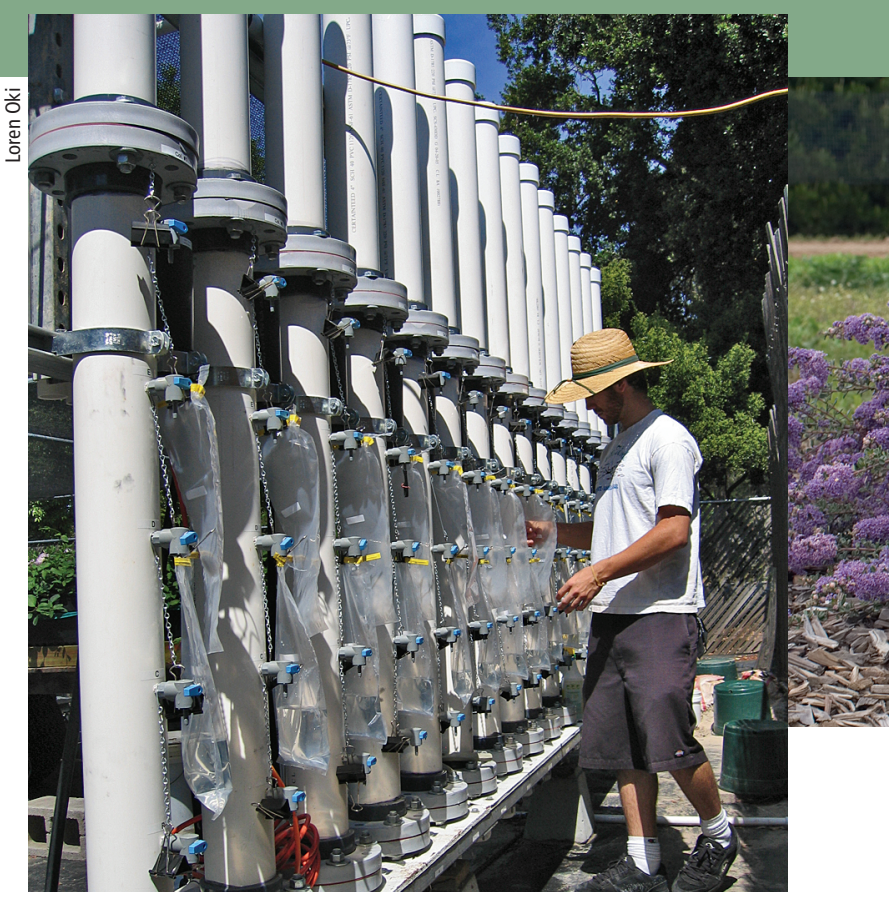

Left, a portable wetland is tested to remove fertilizer and pesticides from nursery runoff; right, UC Davis graduate student Mike Harris collects samples from sand filtration columns. Both technologies could help limit the spread of Phytophthora ramorum, which causes sudden oak death.

water-infrastructure spending; his Delta Vision Blue Ribbon Task Force will report its recommendations by January 2008.

Maintaining and upgrading the quality of surface waters is key to addressing the current crisis. To help protect streams and other surface waters, UC researchers are developing innovative, low-tech ways to control runoff pollution from farms, nurseries and cities. Runoff can carry pathogens, pesticides, nutrients and sediment, or change the temperature of waters where fish and other aquatic species spawn.

\section{$E$. coli in farm runoff}

Water quality often intersects with human health concerns. On Central Coast farms, for example, spinach was contaminated with a virulent strain of E. coli in fall 2006. These fecal bacteria can spread in water, and a leading theory holds that wild pigs may have tracked them from a nearby cattle ranch to the spinach field.

This spinach outbreak helped lead to the establishment in spring 2007 of the Center for Produce Safety, to be located at the UC Davis Western Institute for Food Safety and Security (WIFSS). The Center, which is funded primarily by the Produce Marketing Association and Taylor Farms of Salinas, will focus on facilitating information exchange, research and field training to reduce produce-related health risks.

"One issue is potential conflicts between food safety and water-quality practices," says Rob Atwill, WIFSS director and Cooperative Extension specialist 


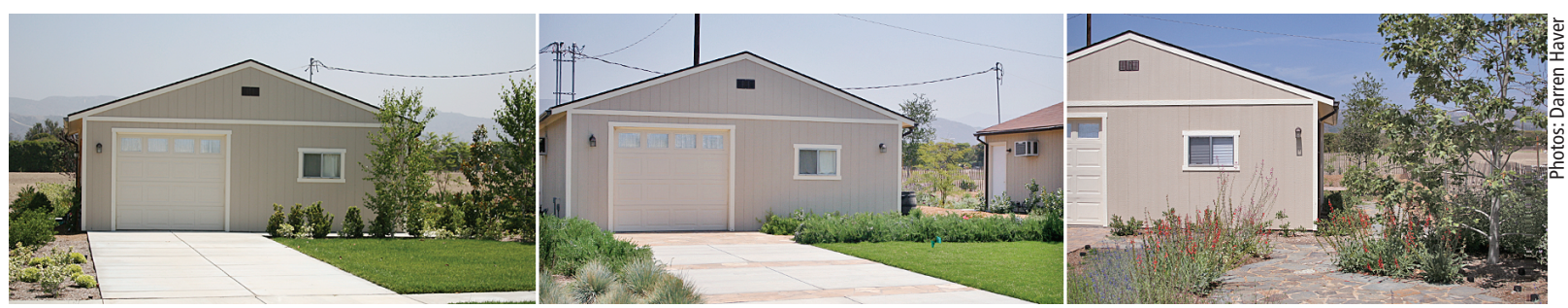

UCCE water-quality advisor Darren Haver is assessing three demonstration landscapes for the volume of runoff and pesticides. Left to right, typical high-, intermediate- and low-runoff homes.

Haver says. But most farms there have been replaced by single-family homes, and while little is known about their impact on water, recent studies have revealed that urban stream sediments have high pesticide levels.

To see if there is a direct link between residential runoff and surface-water pollution, Haver built three demonstration landscapes that span the spectrum of water use. Landscapes account for about half of residential water use, and much of this flows into gutters and concrete-lined storm channels that drain directly into streams and other surface waters.

Haver designed his demonstration landscapes

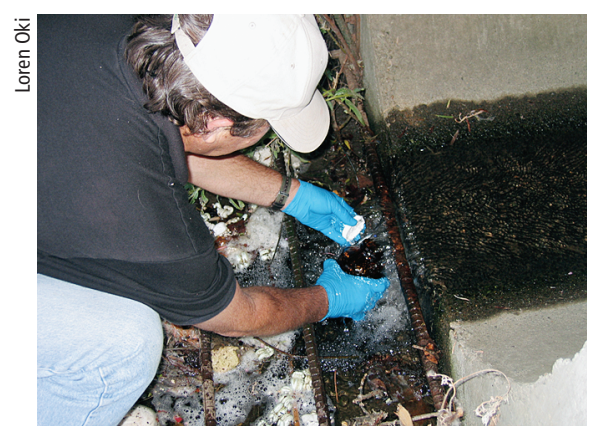
both to assess pollutants in residential runoff and to test recommendations for reducing runoff. His landscapes simulate: (1) a typical high-runoff home with a big lawn, automatic sprinklers, and a concrete driveway and patio; (2) an intermediate-runoff home with a small, drought-tolerant lawn, and a permeable flagstone patio; and (3) a low-runoff home

A large-scale study is looking at runoff in eight Sacramento and Orange County suburban neighborhoods. UC Davis program coordinator Robert Mazalewski collects a sample for analysis. with native plants, drip irrigation, and an interlocking paver driveway and patio.

So far, the results suggest that pesticide levels are high in residential runoff. "We need to design our landscapes to keep water and pesticides on-site," Haver says. When water soaks into the ground instead of running into the gutter, the pollutants in it also stay put. That gives the pesticides time to break down into nontoxic compounds. In addition, simply conserving water, which reduces runoff, would also do a lot to safeguard streams and other surface waters.

In addition, Haver and Oki are part of a large-scale study of residential runoff. This is the first study characterizing residential runoff and it's easy to see why - it took more than 6 months just to identify the study sites. There are four neighborhood sites in Sacramento and four in Orange County, and each has 100 to 400 single-family homes and no multifamily, commercial or agricultural land.

"The beauty of this study is that each site is the residential equivalent of a watershed, with the runoff ultimately flowing into a single storm drain that then feeds into a surface water," Oki says. "This makes it possible to sample runoff from an entire neighborhood at a single point."

As in the small-scale demonstration landscape study, this large-scale neighborhood study shows that residential runoff has high levels of pesticides. "There are spikes associated with the first storms of the season," Oki says. These pesticides are pyrethroids and fipronil, which are used to control ants. Many homeowners have pest-control services that spray around the house exterior once a month, and the pesticide buildup washes away in the first rains.

By combining the results of these two studies, the researchers will determine whether outreach can reduce residential runoff. The outreach will be based on what works best in the demonstration landscapes, and will be delivered intensively to residents in half the neighborhood study sites. If this is effective, the "outreach" sites will have less runoff than the "nonoutreach" sites.

\section{Native plant landscaping}

To encourage more low-runoff landscaping in California, Oki and UC Davis graduate student Karrie Reid are identifying overlooked native plants that could appeal to mainstream gardeners. This work is part of an initiative for the commercial introduction of native plants sponsored by the UC Davis Center for Urban Horticulture, which was established in spring 2007. In contrast to native species, many nonnative garden plants need plenty of water during California's dry summers, as well as insecticides for pests that survive the mild winters. Initially, Oki and Reid are testing six native species that have performed spectacularly in the UC Davis Arboretum, including Apache plume (Fallugia paradoxa), a shrub with abundant 1-inch white flowers, and orange columbine (Aguilegia eximia), a showy perennial with 6-foot-tall flower spikes.

Finding effective ways of reducing residential runoff is increasingly important as the state's population continues to grow. "Do outreach and conservation really work?" Haver asks. "Or do we need someone to go around and give tickets?" - Robin Meadows 